\title{
ARTICLE
}

\section{Critical Social Justice Leadership: Putting "Community" Back in Community College}

\author{
Diane Carlson, Faculty, Folsom Lake College
}

\begin{abstract}
This article proposes that connecting to and understanding the experiences of the communities and students served must become a priority of community college work at all levels. Findings add to the understanding of social justice issues in relation to community colleges and include medium-high to high positive correlations between accuracy of knowledge of social justice issues impacting students and communities and the valuing of social justice practices. These strategies culminate in what the author calls a new model of leadership: Critical Social Justice Leadership (CSJL). Recommendations include stronger social justice training for leaders in educational leadership programs and Boards of Trustees, the incorporation of social justice understandings into ac-

creditation standards, as well as the collection of broader and deeper data to more fully understand and address student outcomes. Through an examination of literature and data from interviews with ten California community college leaders, this article explores the rhetoric of achievement (and now student success) in relation to social justice realities and community college leadership. The article then shifts to exploring the Critical Social Justice Leadership model as a way to illuminate the connection between the systemic social justice realities impacting the communities served by community colleges and the kinds of leadership strategies that might more thoroughly and effectively address issues relating to student success.
\end{abstract}

Educational leaders acknowledge racial gaps in relation to "achievement" (Moore \& Shulock, 2010; Wagner, 2008; Ladson-Billings, 2006) but discussions of the larger equity issues impacting education such as wealth disparity and segregation are startlingly absent from both public and leadership discourse. Further, the emphasis on the Achievement Gap as the problem in education masks the larger inequities of separate and unequal schools associated with segregation and economic inequality (Cross, 2007). Through an examination of literature and data from interviews with ten California community college leaders, this article explores the rhetoric of achievement (and now student success) in relation to social justice realities and community college leadership, then shifts to explore the Critical Social Justice Leadership (CSJL) model supported by the research. My goal is to offer the Critical Social Justice
Leadership model as a way to illuminate the connection between the systemic social justice realities impacting the communities served by community colleges while shedding light on the kinds of leadership strategies that might more thoroughly and effectively address issues relating to student success. Finally, I offer four recommendations for community college leaders, boards of trustees, accrediting bodies, and other community leaders and policy makers to consider. Overall, connecting to and understanding the experiences of the communities and students served must become a priority of community college work at all levels.

Research on the achievement gap has tended to focus on the internal processes within schools, such as teachers' perceptions of the achievement gap and the connection to their own assumptions about students (Uhlenberg \& 
Brown, 2002). Other processes include micro-level causes for the "gap" such as youth culture and student behaviors, schooling conditions or practices, and individual family conditions (Lee, 2002). Still other issues relate to diversity within an institution (Nieto, 2000) and an emphasis on how multicultural curriculum and pedagogy (Banks, 2001; Stovall, 2008; Okoye-Johnson, 2011) positively impact "achievement."

A growing number of scholars argue that it is essential to consider social inequalities as part of any educational policies (Rumberger \& Willms, 1992; Bower, 2011; English, 2002; Rothestein, 2004) and that out-of-school factors must be considered since the achievement gap begins and widens outside of school (Bower, 2011; Melguizo \& Kosiewicz, 2013). Ladson-Billings (2006) and Cross (2007) offer a similar set of critiques of the achievement gap literature and challenge us to reconsider where to place our funding and energies if we sincerely wish to transform our educational system into one that is socially just and truly supportive of student success. These scholars argue that by focusing on the achievement gap as the problem in education we conveniently ignore the massive structural inequalities such as segregation and wealth inequality that got us to this point in the first place.

Cross (2007) argues that the gap is actually one in opportunity and quality of service combined with assumptions about the innate capabilities of poor, urban students of color. Ladson-Billings (2006) relates these structural inequalities and gaps in service to the educational debt which include an oppressive history, economic abandonment, and social and political exclusion. These are all societal debts with huge educational consequences that we have barely begun to consider how to pay down. Meanwhile, wealth gaps and achievement gaps continue to grow. Ladson-Billings recognizes that the attention placed on the symptoms directs us to short-term solutions that cannot address the larger, underlying societal problems. How might gaps in wealth, residence, service, expectations, opportunities, and leadership impact student outcomes? We turn to this next in relationship to community colleges and the so called achievement gap.

\section{Achievement and Community Colleges}

Two sets of researchers (Gandara, Alvarado, Driscoll \& Orfield, 2012 and Martinez-Wenzl \& Marquez, 2012) from the UCLA Civil Rights Project bring questions about achievement into the community college context. They largely focus on access, transfer, and affordability, while still recognizing the structural inequalities impacting many students attending community colleges. Moore and Shulock (2010) also look at achievement in terms of completion and transfer but tend to frame arguments for exploring these issues in terms of economic need, as opposed to economic marginalization causes, and assume the "deficit" model that sees students failing rather than institutional structures and systems failing students. Beach (2011) adds that because attending community college in California has been so affordable, it has been "easy to blame students for their lack of ability or motivation rather than targeting the social environment for structuring the failure of nonwhite students" (p.94) and that the "achievement gaps" that exist do so in this historical context of racial and economic discrimination. Harbour (2014) adds that the highlighting and focus on the Completion Agenda comes at the expense of the essential role of community colleges in supporting the needs of the communities they serve.

Santamaría and Santamaría (2011) and Santamaría (2012) introduce connections between leadership in community colleges and social justice. Santamaría (2012) offers one of the earliest looks at the achievement gap in community colleges in relation to leadership practices. While Moore and Shulock take a "deficiency" perspective, Santamaría directly connects equity issues with what she calls "critical leadership practice" - choosing to work for change on a societal level - and suggests that in order to address the achievement gap that leaders must do so in concert with the educators, stakeholders, and especially the community members they serve.

\section{Why Social Justice?}

The discussion of social justice in education has grown over time to incorporate the underlying structures of inequality. Bell (2007) expresses this definition of social justice as recognizing the need for equitable distribution of resources, as well as physical and psychological safety in pursuit of "full and equal participation of all groups in a society that is mutually shaped to meet their needs" ( $p$. 1). Expanding this to the physical institutions that serve students, a social justice oriented institution is one that is inclusive and focuses on "community, participation, [and] comprehension" (Alvarez, 2009) - necessarily requiring a 
broad and systemic look at the contexts in which these educational structures sit. Anyon (2006) merges these concepts and suggests the need for social justice researchers and educational leaders to look at "opportunity structures and policies existing outside of schools" (p.21) to understanding the full range of social justice issues impacting students and their communities. Understanding issues that impact communities also requires looking at the ways that "institutional educational systems" (Bourdieu and Passeron , 2000, p.54) can reproduce systems that maintain power relationships as they are. An emphasis on achievement and completion in both K-12 and community college conflicts with notions of opportunity and access (Harbour, 2014) by redirecting resources and attention away from the reality and needs of separate and unequal schools.

\section{Leadership and the Social Justice Path}

Examining how the leaders and those in power think and make decisions is an essential part of critical inquiry (Anyon, 2006). Using leadership to transform institutions and challenge the status quo is introduced in the concept of transformational leadership (Burns, 1978). Transformational leadership includes the notion of encouraging more than merely the compliance of followers, pushing them beyond themselves, raising their awareness, and going beyond the call of duty (Burns, 1978; Bass, 1985; Santamaría \& Nevarez, 2010). Bass (1985) brought this idea into management and recognized the need for leaders to have a strong, confident vision. Nevarez and Wood (2010) connect transformational leadership practices to the education system and the ways that leaders can greatly impact community colleges. Practices include identifying barriers and underlying problems, understanding issues through dialogue and contextual analysis, designing institutional policies and practices to address the issues, implementing the appropriate programs, assessing effectiveness, and revising practices and policies based on assessments (p.92). Shields (2004) shifts the idea of transformational leadership toward "transformative" leadership to acknowledge that "needed changes go well beyond institutional and organizational arrangements" (p.113). An underlying assumption based on the literature is that change must be participatory and collaborative (St. Clair \& Groccia, 2009).

While transformational and transformative leaders use their vision to empower and transfigure the personal values of those around them in support of the mission of an organization, Greenleaf (1991), Spears (1996), and Ferch (2003) argue that "servant-leadership" is required to actually transform inequitable systems and to engender socially just outcomes by becoming allies with the least powerful and making sure that their voices are heard and their needs are served. The servant-leadership literature assumes that the interests and needs of communities being served come before the needs of leaders (Santamaría \& Santamaría, 2012). This is similar to the way that Freire (1974) describes change that "must be forged with, not for, the oppressed" (p.33), as "for" suggests a continuing relationship of power and domination but "with" creates the opportunities for service and alliance. Wheatley (2006), as well, explains the need for "co-creating an environment" (p.46) that allows for those in power to step back in order to support connection and creativity.

Social justice issues are implicated in servant-leadership but social justice leadership itself requires vision, action, self-reflection, and an understanding that leadership must be participatory and collaborative (Kezar, 2008; St. Clair \& Groccia, 2009). All must be present to further the processes of service and justice. The concept of selfreflection in social justice leadership includes leaders' examination of their own racial identity (Ellis, 2004; Hays, Chang \& Havice, 2008; Han, West-Olatuni, \& Thomas, 2010) to understand their relationship to cultural competence, privilege and power. Santamaría (2012) suggests that a serious examination of power and privilege not only in the structures that intersect with educational institutions but also in relation to leaders' own positions and identities can transform leaders of any background into leaders who choose to most effectively serve their communities and work for change.

\section{Social justice Leadership and Community Colleges}

In the community college context, Santamaría (2012) calls for critical leadership practices to address issues of achievement and suggests that institution-wide "courageous conversations" (p.17) on equity issues are necessary to begin to understand the relationship between them and success in community colleges. Santamaría (2012) also invites leaders to recognize that equity and success are strongly tied to institutional inequalities, thus requiring them to actively confront these inequalities. Aragon and Brantmeier (2009) suggest a similar encouragement 
Table 1

Social Justice Strategies

\begin{tabular}{lll}
\hline \multicolumn{1}{c}{ Visibility } & Earning “Citizenship" in a Community & Intentionality \\
\hline CEO & Building trust and relationships with & Action \\
- on campus & the communities served & Responsibility \\
- with students & & Educating and Empowering Others \\
- in community & - faculty/staff \\
& - Board of Trustees \\
& - students \\
& - community and beyond \\
& Crtical Consciousness \\
College & - self-reflection and education \\
- in community & Naming, making visible structures of \\
- with families & inequality \\
- with business & \\
\hline
\end{tabular}

of community college leaders to support equity agendas and to be guided by "diversity-affirming ethics" (p.49). Social justice leaders who truly wish to serve must be able to think long-term, grasp both history and the now to realize where we are going, while nurturing the many aspects of community to the benefit of all.

This literature advances the overall need for a better understanding of the kind of role that community college leaders can play in supporting they communities they serve. The following section incorporates data from interviews with California community college leaders to establish the essentials of what community and student centered, socially just, community college leadership can look like. These leadership essentials are then brought together in the Critical Social Justice Leadership Model, presented as a complement to Santamaría's (2012) model of Transformative Critical Leadership.

\section{Critical Social Justice Leadership}

The Critical Social Justice Leadership strategies that come out of the analysis of the interviews that are the basis of this research show the possibilities and potential for community college leaders to recognize the systemic challenges, incorporate this bigger picture into educational success strategies, and advocate for the full range of student and community needs. Ten interviews with California community college presidents and chancellors (designated CEO 1-10) were conducted for this study. The goal was to expand on the issues presented in the literature and explore the intersectionality of achievement, social justice leadership, and community colleges. These one-hour to hour-and-a-half interviews were conducted over three months and reveal a deeper understanding of how community college leaders can better serve their students and communities.

Critical Social Justice Leadership themes show that social justice practices are possible through the strategies of visibility, earning citizenship in local communities, and intentionality. The three strategies presented here are not the only possible sets of social justice practices, but they do represent a necessary trajectory of practice from critical self-reflection extending out to active service to the communities served. These elements work together to build a strong foundation of social justice leadership strategies. The first set of strategies cover the importance of visibility of the CEO and for the college itself. The second area introduces the notion of earning citizenship in a community to build sincere relationships beyond the almost clichéd use of "collaborations." The final area examines the concept of intentionality; borrowed from the realm of philosophy (Searle, 1983) and customized to address what it means to go beyond good intentions and to infuse practices with purposeful actions. 


\section{Visibility}

One of the overarching social justice related themes suggested by these CEOs is the idea of visibility, both on the part of the CEO and on the part of the college itself. These CEOs consistently show that working for social justice whether it is the "full and equal participation of all groups in a society" (Bell, 2007) or some version of that which is empowering, encouraging, and supportive of student and equity needs requires an obvious presence as a starting point and as a basis for building relationships. Several CEOs characterized their leadership roles in relation to visibility:

I show up at the AB 540 club and say I'm here. I show up at the LGBT club at their first meeting and let everyone on campus know that I'm going to be there, won't you join us? We are in an environment where LGBT has been not very comfortable on campus. But, you know, the president shows up and who wants to challenge me? In your face. Who wants to challenge me that these people are welcome on campus here? - CEO 1

The job of the presidency is really - I find a lot of it has to do with having strong interpersonal relationship skills. Because you need people. But you can also educate them and so it's part of my job to speak up when necessary. Or to suggest alternative ideas.

- CEO 2

Being very visible personally...showing up at student events and saying, "Wow, I'm delighted you are doing this!" Thanking them for their activism. Helping them see themselves as part of that system that is empowering - not just for themselves but their peers, as adults, is extremely powerful to those individuals, but it's visible for everyone on campus to see. I mean there is a symbolic role for the president and I am good at Kabuki. It is very important to exaggerate movements and my visibility with students is that exaggeration.

- CEO 1
Just as the president needs to be visible so also does the college or district itself:

...the college realized that doing little activities, summer programs, workshops - if you have a community education program and you do activities with children, that brings the family then. They feel connected.

- CEO 4

These quotes pull together the theme of visibility, exaggerating presence and action to draw attention to the practices being utilized. Bringing out ideas, making spaces to discuss them and drawing attention to that are part of necessary social justice leadership practices.

\section{Earning "Citizenship"}

Citizenship is intertwined with visibility because part of earning a place in a community is by being an obvious and active presence in that community. This theme, however, is set apart from the general theme of visibility for two reasons. One is that in this study the concept of citizenship in a community stands out as unique and should be brought forward. The second reason is that while visibility may be an important part of earning citizenship, visibility is not sufficient in and of itself. This idea stems from one interview in which the CEO shares an experience:

The greatest honor I have been given - a very recent honor - a community sort of radio personality, a community leader person granted me a "doctorate in education, from the University of the Hood." That's street cred for me. Very important for a white man from the other side of the world in [this community]. Okay? To have our congress member introduce me on-campus, on my campus, to her constituents as somebody who is well-positioned in the community, who knows our issues, gives me citizenship and I call it that to her face. She's granting me citizenship in our area ... that opens doors for me to say, yes, I am a community activist and I have the cred, I have the acceptance to be able to be a community activist to bring people on campus, increasingly to have engagement between town and gown.

- CEO 1 
When you've got all these different layers of the community, the president can be out there, but what if they only attend the Chambers and never really get into some of the social service organization to understand what's really going on in the community to get a broader picture? - CEO 2

If community college leaders consider that part of their CEO role is to earn the trust of the community beyond simply being visible, this adds a significant dimension to the kinds of collaborations and relationships that can be developed. Many of the CEOs in this study mention collaborations and partnerships with community groups and businesses, but it is not always clear what this means beyond it sounding nice that some sort of link exists beyond the campus boundaries. Creating partnerships is one thing, but building trusted relationships in which leaders have earned their "citizenship" in the community, by actively working to understand and advocate for the communities served, affirms the necessity of that relationship. Freire (1974) describes leadership and change as being "forged with, not for, the oppressed" (p.33), which also connects with concepts of servant-leadership (Greenleaf, 1991). The idea of earning citizenship encourages us to rethink the power arrangement by placing the needs of the community before the needs of the leader. Community college leaders may need to do this to establish that trusting relationship with the community and to learn what issues impact students and what programs and practices will best serve them.

This sincere process of earning a trusted place in the community is also connected to John Dewey's vision of democratic communities and the health of our democracy being intertwined with health of our education system (Harbour, 2014). Harbour (2014) argues that democratic communities, especially as they relate to community colleges, require this same connection to gaining knowledge and understanding of the issues being faced by the college communities as is suggested by the concept of earning citizenship. Education serves democracy best when it is used to inquire and challenge socially unjust conditions. When community college leaders gain critical understanding about the communities they serve by earning their place, they gain credibility and acceptance to de- velop and support practices in alliance with communities that will more fully address the needs of their students.

\section{Intentionality}

The strategy of intentionality is intertwined with the other strategies, but it is actually where leaders should begin. It illustrates that social justice is not accidental and a mere desire for it to exist does not create a social justice practice. It must be fought for both on a personal level, through self-reflection, as well as on a practice level. The word "intentionality" is lifted from the discipline of philosophy which uses the idea to show how states of mind can be "directed toward some goal or thing" (Jacob, 2010). Borrowing this word and saturating this state of mind with action captures the necessary directed behavior and selfinterrogation that must accompany practices. Intentionality also involves using power to educate others from the administrative cabinet, out across the campus to staff, faculty, and students, to Boards of Trustees, and out to the community about the social justice issues impacting students. The action subtheme involves accepting responsibility along with direct and persistent interventions:

We have to act to counter the experience that students have had throughout their entire childhood that says keep your head down, don't look the policeman in the eye, don't cause any trouble in the classroom, don't distinguish yourself or you will be picked out, obey ... and here I am saying functionally my job is in fact to enforce the behavior standards on campus; in practice, my job as a social activist is to undermine those efforts.

- CEO 1

I think that too many of our chancellors and presidents, CEOs, lose sight of that social justice agenda.

- CEO 8

I'm in education because it's a calling, it's an obligation, it's a responsibility to create a path so that these things can be fulfilled ... I think we've waited long enough. People of color have suffered long enough ... students have been im- 
pacted negatively by the structure of society so I see it as part of my responsibility to change that as soon as possible.

- CEO 9

I want people to hold us accountable because if the college doesn't see that we are being held accountable by the community and if we do a good job, the community is going to reward us by sending their children here, their family members and what have you.

\section{- CEO 5}

CEO 5, here is not only referencing accepting responsibility, but also the idea that the community should play an essential role in holding the college responsible for meeting community needs. This is a shift in power, a shift toward communities determining their needs and becoming partners with community college leaders to meet those needs. Once more, the active commitment to develop an understanding of community needs and build shared vision and practice with those impacted empowers that community and creates greater democratic involvement (Harbour, 2014).

Educating and empowering faculty, staff, and community are also a part of intentionality. Some of these CEOs recognize the role that the college can play in bringing information and knowledge about issues impacting students and that sharing information and actively participating in campus and community education on social justice issues is essential:

...part of my role is to bring out the issues and educate our own students, and faculty, and staff. You don't know what you don't know. And so sometimes the role of the college as a learning institution should be to provide that information.

- CEO 2

But you find one person, you create a champion. You give them some professional development and then you let them go because you have to assume that they're there to help students and so I help them to help our students.

- CEO 9
Another aspect of intentionality involves naming and making visible the structures of inequality that impact communities and the students they send to community colleges. Part of social justice leadership practice therefore is coming to understand these issues and speaking up audibly on what these structures are and how students are impacted:

I think that the wealth issue should be heavily featured in our presentation of data and our narrative analysis. Take the scorecard that's out right now. It does have demographic data but the wealth data is less available. And it really does affect policy ... there's unintended consequences of some of our policies.

- CEO 3

Well, you certainly can't be afraid to articulate the issues. So I guess the first thing is to be willing to step forward and identify the issues that need attention. And even though you may have people within your own organization who don't want to hear that message or people within the broader society who don't want to hear that message, you may have to still bring it, but you have to bring it into the context."

- CEO 7

The final component suggested by intentionality is critical consciousness. This concept underscores all of the strands of intentionality. Freire $(1974,2013)$ describes the process of developing this critical consciousness through dialogical action and reflection as conscientização, an awakening of understanding about the oppressive conditions that exist, combined with action to transform them. While Freire uses this concept to describe how the oppressed take control of their circumstances, the concept can also be a part of the development of community college leaders as they begin to educate themselves, to grapple with their own privilege and power (Mclntosh, 2007; Leonardo, 2004), to see how to both transform colleges so that they do not replicate the community conditions, but also to actively address those conditions and the impact on students. 


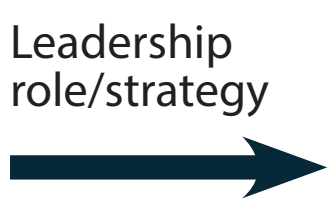

1 Choose change

2 Understand issues

3 Convince others

4. Courageous conversations

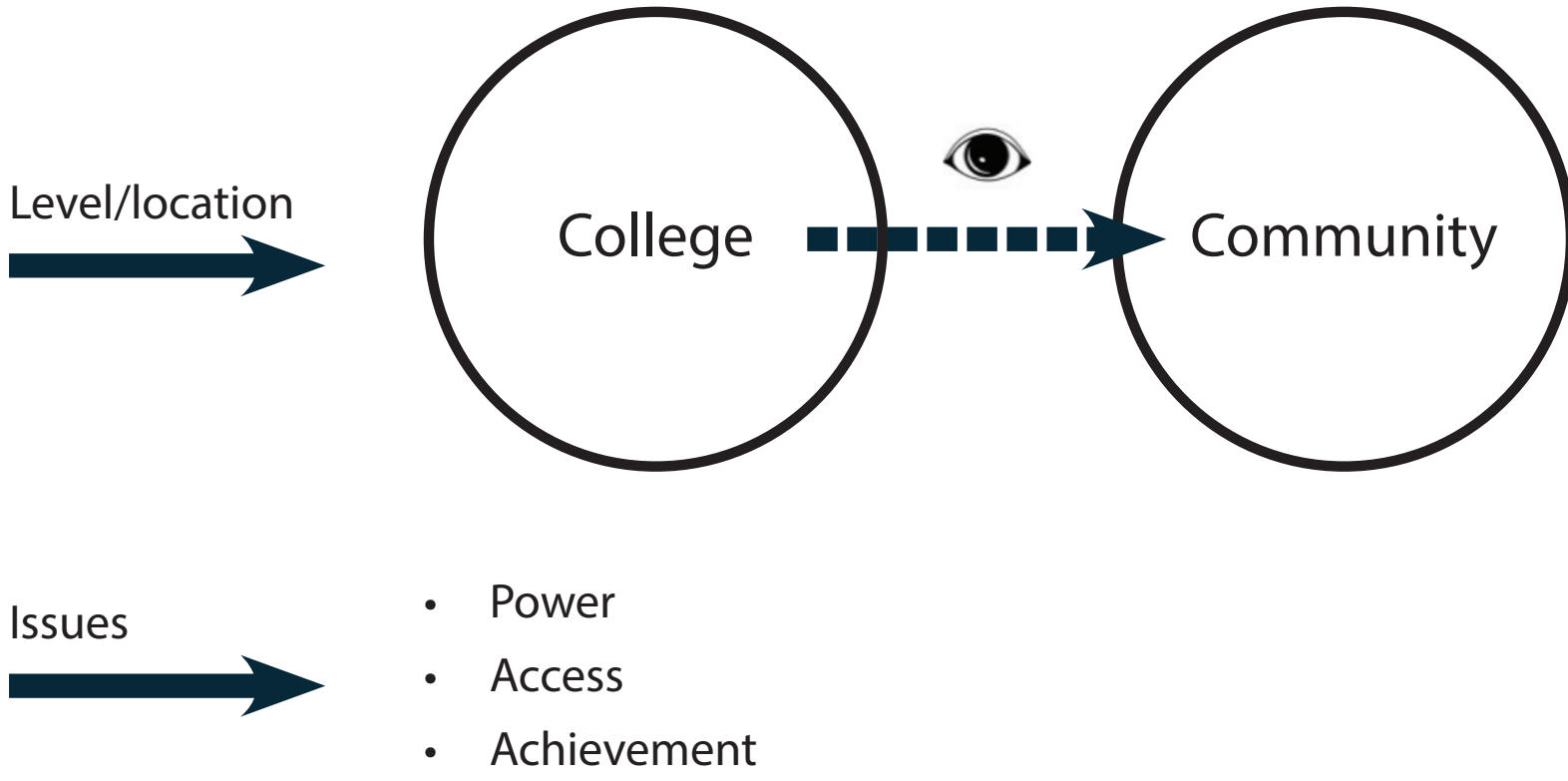

Figure 1. Transformative Critical Leadership (Santamaría, 2012).

\section{The Critical Social Justice Leadership Model}

The strategy themes that come out of these interviews are manifested in the Critical Social Justice Leadership Model. This model shows a more complete image of how CEOs or any community college leaders can engage in critical social justice practices. Visibility, earning "citizenship," and intentionality connect agreeably with Santamaría's (2012) concept of transformative critical leadership and extends the concept to the work that community college leaders should also do as part of engaging with the communities they serve. In fact, the theme of earning "citizenship" makes this extension a requirement of social justice leadership practice. The following models present the concept of transformative critical leadership by Santamaría (2012) and then the extension of that in the Critical Social Justice Leadership Model that comes out of this research.
Santamaría's (2012) transformative critical leadership model largely focuses on the college itself as an institution in which power plays a large role in the kinds of equity issues that are recognized and presented as real impacts on students. This model addresses some of the institutionlevel social justice needs of community colleges such that the college becomes a transformative institution through the critical leadership that creates spaces for courageous conversations and actions on issues to occur. These strategies occur with an eye on what is happening in the community and in society as a whole (Santamaría, 2012). Santamaría also suggests that this model can be used to address some of the indicators presented by Nevarez and Wood (2010) in relation to "achievement" issues such as "remediation, retention, graduation rates, and transfer" (Santamaría, 2012, p.21). 
1 Visibility: of CEO and College

2 Citizenship: becoming part of community

Leadership role/strategy

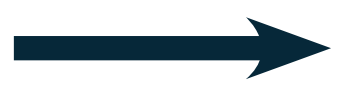

3 Intentionality:

- Action

- Critical Consciousness

- Responsibility

- Education/Empowerment

- Naming/making visible structures of inequality

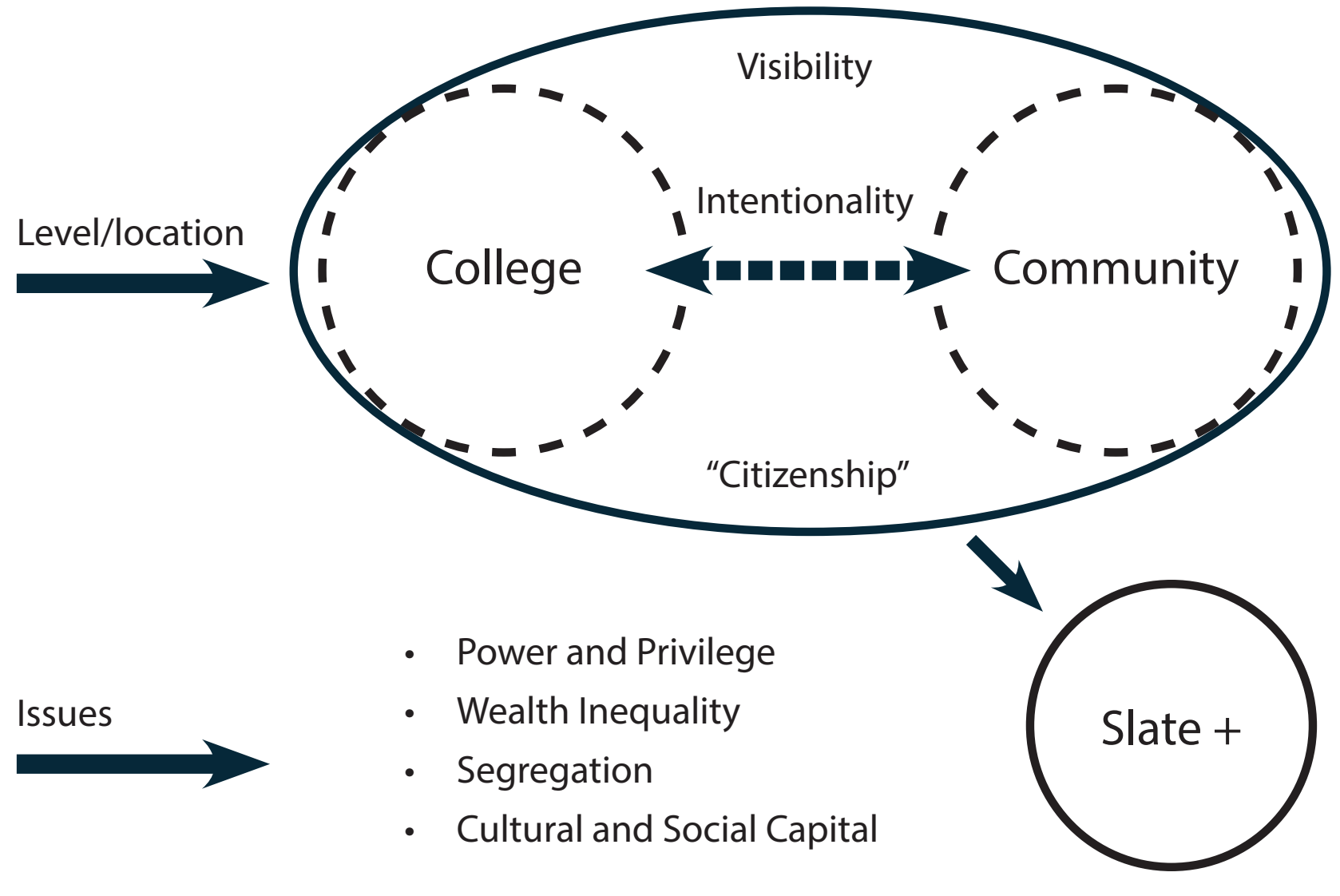

Figure 2. Critical Social Justice Leadership Model. 
While Santamaría's (2012) transformative critical leadership model focuses on the micro-level work of the CEO, the Critical Social Justice Leadership model that emerges from this research extends transformative critical leadership to overtly include the strategies of visibility and earning citizenship in communities served, as well as the development of critical consciousness, responsibility, and the naming of structural inequality issues through intentionality. The relationship between college and community becomes more permeable and connected through these strategies and through intentionality, in particular. While much of the work that community college leaders will do in this model still connects to the important transformative critical leadership work that Santamaría (2012) advocates for on college campuses, the Critical Social Justice Leadership model emphasizes the essential connections to the communities served by colleges and districts and provides for stronger, sincere coalitions and alliances to address the continuing structural inequality issues impacting both communities and the students they send to community colleges.

The data and this model suggest four recommendations. Each of these recommendations provide support for not only community college leaders to do the essential social justice work that their communities require but also for policy makers and the general public to develop broader understandings of the systemic issues impacting communities everywhere and how these issues impact success. Responsibility and connection to others are an essential part of the intentionality required for social justice practice and strategies. The Critical Social Justice Leadership model also opens the possibility that communities and their colleges can connect in ways that can more strongly advocate for their needs on state or other bases. We turn next to the four recommendations based on this study.

\section{Recommendations for Action} RECOMMENDATION \# 1

Critical Social Justice Leadership strategies should be incorporated into community college leadership education and work.

Although the strategies of visibility, citizenship, and intentionality are related to each other, they each point to different facets of leadership. The concept of visibility is one of the obvious ways that the CEO represents to the campus, to students, and to the community what the college (and the CEO herself) values. If students are whom we serve, we need to be visible in all aspects of their relationship to the college; this means not just current students but also potential students. It also means visibility with businesses and families that support these students. Earning "citizenship" is the way that the CEO or other community college leader becomes part of the community. This is about building trust and sincere relationships such that the CEO can have credibility to know what issues students are facing and then what policies might be most effective. This concept is what puts the "community" in community college. Intentionality is what brings a CEO's good intentions into actually working with communities and their needs. It requires no additional resources to name what is happening in a community, to make it a persistent public message that a CEO or college is willing to acknowledge the consequences of inequitable practices and policies and to continue to put that out there to the campus, the community, the Boards of Trustees, the accreditors, the policymakers. While this alone does not constitute social justice practice, making invisible structures visible is a powerful part of beginning to undermine aspects of education that replicate and reproduce the inequitable status quo. Community college leaders need not be experts on all social justice issues to be effective leaders, but if they incorporate Critical Social Justice Leadership practices they will be less fearful and able to more meaningfully address the full range of student and community needs.

\section{RECOMMENDATION \#2}

Incorporate training on social justice issues into the support provided to Boards of Trustees by the Community College League of California to better serve communities and to best hire, support, and retain CEOs who are committed to social justice work.

One of the roles of the Community College League of California (CCLC) is to provide leadership and professional development to the Boards of Trustees that serve community colleges and Districts ("Leadership Development," 2014). This provides a meaningful opportunity to incorporate understandings of the experiences and impacts of segregated, inferior education on the students who do and will attend community colleges and to incorporate that understanding into policies developed and implemented by the Boards and the CEOs they hire. The Trustee 
Handbook produced by the CCLC offers a definition of "equity," which connects colleges and districts to issues impacting students before they even arrive at a college:

Equity refers to the effort to ensure that people from all ethnic and socio-economic backgrounds have the skills and knowledge to benefit from and succeed in the colleges - to close the 'achievement gap' between students from different demographic groups. (Smith, 2013, p.3)

This section does not limit the role of boards to what happens to students after they arrive at a college or district. An interpretation of this could be that boards and the work they do on social justice issues through CEOs and the colleges could be occurring simultaneously in communities and on campuses. This is further supported in other parts of the handbook (Smith, 2013) that elaborate on the role of boards: "A board's primary allegiance should be to the external community and public good" (p.45).

Colleges can be insular institutions. One of the values of lay boards in higher education is to provide disinterested leadership and ensure that colleges are responsive to the broader community. Board members use their perspectives and knowledge to insist that faculty and administration understand the framework of the larger world. They ensure that educators are aware of needs and changes in the external communities that may influence the college mission. (p.48)

These points require direct observation of the larger circumstances impacting communities as they create policies to address the needs of students. And finally, of the 9 bulleted points listed for Trustees to consider when establishing goals and indicators for their colleges or districts, 3 of them either directly or implicitly could connect to social justice issues and establishing social justice agendas, including the following two points:

Specific areas to explore when establishing goals and indicators might include:

What important demographic, economic, and social trends in the state and in the local com- munities affect the colleges? How is the district responding to these trends? ... How has the college contributed to the cultural, economic, and social health and stability of the community? How is that measured? (Smith, 2013, p. 87)

CEOs cannot do what is already difficult work if their boards do not understand the social justice issues thoroughly or if the boards do not provide the necessary support for their CEOs to do this work.

\section{RECOMMENDATION \#3}

Incorporate social justice issues into the development of accreditation standards and training for accreditors implementing those standards.

Even those Boards of Trustees and CEOs who are working to redirect attention toward the larger social justice issues impacting students and communities are nevertheless compelled to pay a significant amount of attention to outcome accountability measures because the Accrediting Commission for Community and Junior Colleges (ACCJC) standards do not include or incorporate any of the essential structural inequality issues as part of understanding or addressing the outcomes they evaluate. Where is the "community" in these community college standards? These standards, while asserting to support student learning, are focusing on outcomes without context and without assessing the creative and meaningful input that could be occurring as colleges and their communities work together to address the long standing structural barriers that remain and impact students. As the ACCJC becomes part of the process of evaluating the inputs, standards can shift to promoting the community and college links necessary to truly know and understand what the needs are and how to work together collaboratively to address structural inequalities and meet those needs.

\section{RECOMMENDATION \#4}

Collect all relevant, deeper and broader data to understand the full contexts from which students come and which impact success.

Deeper data requires more contextual, demographic information. Although there is some college entry data such as placement data, most is largely collected on the backend of the college experience in terms of student 
learning outcomes. Very little data is considered from the larger context in which a college sits. Student Success Score Cards do disaggregate data to show "success" by race, gender, and age but how might including segregation data and wealth inequality improve our understandings of experiences and outcomes? What kinds of policies would it suggest if there are strong correlations or predictive relationships between these deeper issues and the experiences of community college students? We are currently making decisions about outcomes and success and setting policies based on a limited set of information.

CEOs, communities served, and boards of trustees can work together to share broader sets of data, understand how policies and practices interact and impact each other, and facilitate the development of mutually supportive policies. This creates opportunities and programs that benefit more constituents across the community. When community colleges become part of the consideration for policies relating to (for example) affordable housing, library location, K-12 collaborations with community colleges between instructors, and public transportation access, students benefit. If the bottom line is service to students then our policies and practices must reflect a deep commitment to that, not just ones centered on outcomes without context and understanding of experiences and barriers.

\section{Conclusion}

Critical social justice leadership is necessary for understanding the issues that communities served by community colleges are facing. The Critical Social Justice Leadership model provides a meaningful foundation for understanding how those issues impact students and their experiences on college campuses. Evidence consistently shows that diversity and diverse learning environments support student success (Orfield, Frankenburg, \& Garces, 2008; Cooley, 2008) and increase opportunities in all aspects of life. On the other hand, structural inequalities point to gaps in resources, expectations, quality of service and teaching, and opportunities related to racial and economic isolation (Cross, 2007). How CEOs and other community college leaders respond to these realities can either perpetuate the invisibility of the issues or bring them out into the open for coalitions of students, faculty, staff, administrators, community groups and local governments to grapple with fervently.
The themes that arise from these ten interviews with California community college CEOs and that are incorporated into the Critical Social Justice Model suggest that critical consciousness is something CEOs can cultivate in themselves. Accepting responsibility to do social justice work is something CEOs can do as well. If some leaders believe they can lead from a distance and not really know what their students are experiencing, what they contend with every day and what barriers remain in front of them, then they cannot support or create programs that will fully serve students' needs and improve their chances of success. Community college leaders make decisions about and create policies for students who are hugely impacted by racial and economic oppressions, but these same leaders may not have fully addressed or examined their own identities and privileges in relation to these issues.

In turn, however, for the CEOs who have already made these connections and developed their critical consciousness, they need the support of their boards of trustees to continue the difficult work they are doing. If ultimately it will be a social movement that is required to undo these entrenched systems, what role will the CEO play in those movements to come? Will it be as a perpetuator of the status quo or will it be as a partner with the communities served to create and recreate social and educational systems that truly serve everyone? Until community college leaders understand the impacts of systemic social justice issues on the communities they serve they will be less effective advocates for their students and less likely to develop and promote the best policies and practices that will support their students' success.

\section{About the Author}

Dr. Diane E. Carlson is a full-time professor and chair of the sociology department at Folsom Lake College. She is also the faculty chair for FLC's Multicultural and Diversity Committee which supports social justice efforts at the college.

Email:diane.carlson@flc.losrios.edu 


\section{REFERENCES}

Alvarez, J. (2009). Social justice education: A way down from the ivory tower. In K. Skubikowsi, C. Wright, \& R. Graf (Eds.), Social justice education: Inviting faculty to transform their institutions (pp. xiii-xxiv). Sterling, VA: Stylus.

Anyon, J. (2006). What should count as educational research: notes toward a new paradigm. In G. Ladson-Billings, \& W. F. Tate (Eds.), Education research in the public interest: Social justice, action, and policy (pp. 17-26). New York: Teachers College Press.

Aragon, A. \& Brantmeier, E. (2009). Diversity-affirming ethics and critical epistemology: Institutional decision making in community colleges. New Directions for Community Colleges (148), 39-51.

Banks, J.A. (2001). Cultural diversity and education: Foundations, curriculum, and teaching. Boston: Pearson, Allyn and Bacon.

Bass, B.M. (1985) Leadership and performance. New York: Free Press.

Beach, J.M. (2011). Gateway to opportunity? A history of the community college in the United States. Sterling, VA: Stylus.

Bell, L.A. (2010). Theoretical foundations. In M. Adams, W.J., Blumenfeld, C. Castañeda, H.W. Hackman, M.L. Peters, \& X. Zúñiga, X. (Eds.), Readings for diversity and social justice (pp. 21-26). New York: Routledge.

Bourdieu, P. \& Passeron, J. (2000). Reproduction in education, society, and culture. London: Sage Publications.

Bower, C.B. (2011). Social policy and the achievement gap: What Do We Know? Where Should We Head? Education and Urban Society, 45(1), 1-36.

Burns, J.M. (1978). Leadership. New York: Harper \& Row.

Cooley, J. (2008). Desegregation and the achievement gap: Do diverse peers help? (WCER Working Paper No. 2008-7). Madison: University of Wisconsin-Madison, Wisconsin Center for Education Research. Retrieved from http://www.wcer.wisc. edu/publications/workingPapers/papers.php

Cross, B.E. (2007). Urban school achievement gap as a metaphor to conceal U.S. apartheid education. Theory into Practice, 46(3), 247-255.

Ellis, P.H. (2004). White identity development at a two-year institution. Community College Journal of Research and Practice, 28, 745-761.

English, F.W. (2002). On the intractability of the achievement gap in urban schools and the discursive practice of continuing racial discrimination. Education and Urban Society, 34(3), 298-311.

Ferch, S. R. (2003). Servant-leadership, forgiveness, and social justice (Voices of Servant-Leadership Report Series). Indianapolis, IN: Greenleaf Center for Servant-Leadership.

Freire, P. (1974). Pedagogy of the oppressed. New York: Seabury.

Gandara, P., Alvarado, E., Driscoll A., \& Orfield, G. (2012). Building pathways to transfer: Community colleges that break the chain of failure for students of color. Los Angeles: The Civil Rights Project, UCLA.

Greenleaf, R.K. (1991). The servant as leader. Indianapolis, IN: The Robert K. Greenleaf Center.

Han, H., West-Olatunji, C. \& Thomas, M.S. (2010). Use of racial identity statuses as predictors of white privilege awareness. Journal of Humanistic Counseling, Education and Develop- ment, 47, 234-246.

Harbour, C. P. (2015). John Dewey and the future of community college education. New York: Bloomsbury.

Hays, D.G., Chang, C.Y., \& Havice, P. (2008). White racial identity statuses as predictors of white privilege awareness. Journal of Humanistic Counseling, Education and Development, 47, 234-246.

Jacob, Pierre. (2010). Intentionality. In Edward N. Zalta (ed.), The Stanford Encyclopedia of Philosophy. Retroeved from http:// plato.stanford.edu/archives/fall2010/entries/intentionality

Kezar, A. (2008). Advancing diversity agendas on campus: Examining transactional and transformational presidential leadership styles. International Journal of Leadership in Education, 11(4), 379-405.

Ladson-Billings, G. (2006). From the achievement gap to the education debt: Understanding achievement in U.S. schools. Educational Researcher, 35(7), 3-12.

Community College League of California. (2015). Leadership Development. (2014). Retrieved from http://www.ccleague. org/i4a/pages/index.cfm?pageid=3412

Lee, J. (2004). Multiple facets of inequity in racial and ethnic achievement gaps. Peabody Journal of Education, 79(2), 5173.

Leonardo, Z. (2004). The color of supremacy: Beyond the discourse of 'white privilege'. Educational Philosophy and Theory, 36(2), 137-152.

Martinez-Wenzl, M. \& Marquez, R. (2012). Unrealized promises: Unequal access, affordability, and excellence at community colleges in Southern California. Los Angeles: The Civil Rights Project, The University of California at Los Angeles.

Mclntosh, P., (2007). White privilege and Male privilege: A personal account of coming to see correspondences through work in women's studies. In M. Andersen \& P. H. Collins (Eds.), Race, class, and gender: An anthology (6th ed.). Belmont, CA: Wadsworth Publishing.

Melguizo, T. \& Kosiewicz, H. (2013). The role of race, income, and funding on student success: An institutional level analysis of California community colleges. In Bridging the higher education divide: Strengthening community colleges and restoring the American dream (pp. 137-155). New York: The Century Foundation Press.

Moore, C. \& Shulock, N. (2010). Divided we fail: improving completion and closing racial gaps in California's community colleges. Sacramento: California State University, Sacramento Institute for Higher Education Leadership and Policy.

Nevarez, C., \& Wood, J.L. (2010). Community college leadership and administration: Theory, practice, and change. New York: Peter Lang.

Nieto, S. (2000). Affirming diversity: The sociopolitical context of multicultural education. New York: Longman.

Okoye-Johnson, O. (2011). Does multicultural education improve students' racial attitudes? Implications for closing the achievement gap. Journal of Black Studies 42(8), 1252-1274.

Orfield, G., Frankenberg, E.F., \& Garces, L.M. (2008). Statement of American social scientists of research on school desegregation to the U.S. Supreme Court in Parents v. Seattle School District and Meredith v. Jefferson County. Urban Review, 40, 96-136.

Rothstein, R. (2004). Class and schools: Using social, economic, and 
educational reform to close the black-white achievement gap. New York: Teachers College Press.

Rumberger, R.W., \& Willms, J.D. (1992). The impact of racial and ethnic segregation on the achievement gap in California high schools. Educational Evaluation and Policy Analysis, 14(4), 377-396.

Santamaría, L. J. (2012). Transformative critical leadership in action: Re-visioning an equity agenda to address the community college achievement gap. Journal of Transformative Leadership and Policy Studies, 2(1), 15-23.

Santamaría, L.J. \& Santamaría, A.P. (2011). Applied critical leadership. New York: Routledge.

Santamaría, L.J. \& Nevarez, C. (2010). Multicultural/multiethnic education: A critical approach to the educational doctorate in leadership. Paper presented at the Annual AERA International Conference, Denver, CO.

Searle, J.R. (1983). Intentionality: An essay in the philosophy of mind. Cambridge, UK: Cambridge University Press.

Shields, C.M. (2004). Dialogic leadership for social justice: Overcoming pathologies of silence. Educational Administration Quarterly, 40(1), 109-132.

Smith, C.J. (2013). Trustee handbook. Sacramento: Community College League of California.

Spears, L. (1996). Reflections on Robert K. Greenleaf and servantleadership. Leadership \& Organization Development Journal, 17(7), 33-35.

St.Clair, K. \& J.E. Groccia. (2009). Change to social justice education: higher education strategy. In K. Skubikowski, C. Wright, \& R. Graf (Eds.), Social justice education: Inviting faculty to transform their institutions (pp. 70-84). Sterling, VA: Stylus.

Stovall, D., Quinn, T., \& Ayers, W. (2009). Handbook of social justice in education. New York: Routledge.

Uhlenberg, J. \& Brown, K.M. (2002). Racial gaps in teachers' perceptions of the achievement gap. Education and Urban Society, 34(4), 493-530.

Wheatley, M.J. (2006). Leadership and the new science: Discovering order in a chaotic world. San Francisco: Berrett Koehler. 